\title{
Assessment and Intelligence of The Mathematical-Logical in Learning Computer Programming
}

\author{
Komang Setemen \\ Department of Informatics, Universitas Pendidikan Ganesha, Singaraja, Indonesia \\ e-mail: k.setemen@undiksha.ac.id
}

\begin{abstract}
The research objective was to determine the influence of assessment types and mathematicallogical intelligence on computer programming learning outcomes after controlling numerical aptitude. Data were analyzed by analysis of covariance (ANCOVA) two lanes with one covariate. Results showed that as the results of learning computer programming, students who attended the learning process with the assessment portfolio was higher than students who attended the learning process with the assessment project. Besides, on a group of students who had high the intelligence mathematicallogical, the result of learning computer programming was most suitable to follow the process with a portfolio. However, on a group of students who had low mathematical-logical intelligence, computer programming learning outcomes were most suitable to follow the process with the assessment. Research to use the type of portfolio assessment in the learning process in order to improve student results.
\end{abstract}

Keywords: Portfolio Assessment; Project Assessment; Mathematical-Logical Intelligence; Learning Outcomes Computer Programming

\section{Introduction}

Creating a computer program is a challenging job for most of the new students majoring in informatics or computer science. In traditional programming learning, students still need much time to learn the syntax of the program. However, they usually still make mistakes in programming because it has some misunderstanding in the use of syntax program for troubleshooting. It happens because the program requires the ability to make complex cognitive abilities in the process. According to Plimmer (2000: 279), three important parts are interconnected in programming, namely knowledge of programming languages, the ability to solve problems in a creative ability of algorithms, and finally, be able to see the project completed at an early stage.

Based on the experience taught this course in computer programming at the Department of Informatics Management Universitas Pendidikan Ganesha (Undiksha), the author found the fact that many students who fail in this course. Failed in question is the ability to create a computer program from a real problem to be solved is deficient. It can be seen from the tasks given to the students, only a few students can complete the task properly and the total score above a minimum score of completeness following predetermined criteria.

The assessment conducted by the lecturers had only assessed the final product of the work of the students after the students pass the learning process. It is contrary to the concept of effective teaching, which should be done an assessment process that provides feedback to the difficulties experienced by learners. By providing feedback on the difficulties and problems experienced by learners, the learners will have the opportunity to fix it. Moreover, if necessary, the works produced is well documented, so it can be seen the development of learners in achieving competence.

Related to the above, an alternative valuation on the process and results of student learning. Assessment of alternative means of assessment format non-traditional, usually requires the construction, demonstration, or the performance of students. Format alternative assessment is more focused and centered on students, as well as authentic (Doran et al., 1998: 32). According to Uno and Koni (2012: 26), an alternative assessment that has these characteristics is a portfolio assessment. Portfolio assessment can show the progress of student learning through the work of students. Portfolio assessment can be defined as a 
collection of works learners systematically arranged and organized as a result of the effort of learning that has been done within a certain time (Sanjaya, 2010: 363). Marhaeni (2004: 1324) states that portfolio assessment is a procedure to collect information on the development and the ability of learners through their portfolios.

In addition to the assessment portfolio, more authentic assessment formats that can be used is the assessment project (Koyan, 2011: 12). Mahardika (2010: 210) stated that the assessment project is an assessment conducted by educators against the tasks to be completed within a period / specified time. The task of such an investigation since the planning, processing, and presentation of data. Johnson and Johnson (2002: 95) says that the project is a project that aims to produce something about the student on a topic related to the curriculum instead of simply reproducing knowledge of the test. More Wortham (2008: 217) says that the project is an activity undertaken by a student or group of students that are longer than classroom activity performed during a single class period. Projects can be part of a unit in a subject/subjects, such as units of science or social studies, or part of a theme studied in class. Some types of products are the result of a project. An example is to produce some form of computer programs on the topic related content to the general structure of Pascal.

An authentic assessment is not solely directed to obtain a picture of the student's ability to achieve competence, but the results of the assessment should provide feedback to improve the learning process both by lecturers and students so that the learning outcomes could be more optimal. The results obtained by the student learning are the result of a series of the learning process. Sudjana (2002: 3 ) defines that the results of student learning are essentially a change in behavior. Behavior as a result of learning in a broad sense includes the field of cognitive, affective, and psychomotor. Therefore, in the assessment of learning outcomes, the role of instructional objectives containing formulation capabilities and desired behavior controlled by the students becomes an important element as a basis and reference for the assessment. Meanwhile, Mandiartha (2011: 12) stated that the result of learning is the student's ability to meet the demands of the learning indicators in terms of cognitive, affective, and psychomotor; or of the cognitive and affective domains, from cognitive and psychomotor, of affective and psychomotor. Based on these definitions above, the results of learning computer programming is defined as the ability of the students in using the syntax rules of programming language, the reconstruction of the problem systematically, and the final products are made, to meet the demands indicators of learning or competency in terms of cognitive, affective and psychomotor.

Another fact that can be revealed by experience taught courses in computer programming are related to student characteristics. Some students look powerful ability of logic, and it can be seen from the ability to translate into real problems in computer programming. While others tend to have the lower logic capability, thus indirectly affect the ability to make the program as the implementation of real problem-solving. Characteristics of other students are the tendency of students to prefer the work or group work, while others are more like work or tasks to be completed individually. Characteristics of students who liked the task individually have more confidence and higher logic capabilities when compared with students who liked the work that must be done in groups.

The different characteristics of each student could happen because, according to Gardner, that research, there are eight (8) types of human intelligence in understanding the real world (Budiningsih, 2012: 114). Which results of this study gave birth to the theory of the so-called multiple intelligences (multiple intelligences). Further, he said that in general, the intelligence is more prominent or more powerful than others. It can be interpreted that each individual is different, so treat several individuals with the same treatment is not appropriate. The implications of this theory in education are obvious that required great attention to the characteristics of the individual to make the learning process and results are optimal in each individual. In the context of programming, for example, some people prefer to do the work independently because it has the ability of strong mathematics and logic, while other individuals prefer to work in groups because it has the ability of mathematics and logic lower. If it is associated with Gardner's theory of multiple intelligences, math and logic capabilities are called the logical-mathematical intelligence (logical-mathematical intelligence). Logical- 
mathematical intelligence is the ability of logic and mathematics, in addition to the ability of natural science (Gardner, 2003: 23). Logical-mathematical intelligence is needed in the programming process because in order to make the program, a person must be able to understand the logic of the process (process logic) of a problem. Without understanding the logic of the process of a problem, it will be difficult to translate the issue into a computer program.

Same as mentioned earlier that, the achievement of learning outcomes computer programming depends on the type of continuous assessment during the learning process and logical-mathematical intelligence possessed by each student. In addition to the type of assessment and logical-mathematical intelligence possessed by students, other factors such as students' talent also need to be considered. According to Munandar (1992: 17), talent (aptitude) is generally defined as an innate ability, as the potential that still needs to be developed and trained to be realized. According to Radili (2009), the potential of individuals there is general and nothing in particular. Including general intelligence capabilities, while the ability to specifically refer to the talents of individuals who are usually referred to as a special talent. Special talent is a set of values that is considered a sign of the ability of individuals to receive training or response, such as language skills, music, math, mechanics, and sports. Special talents related to computer programming talents are numeric (arithmetic). Martin and Beena (2012), reveals that good numerical aptitude of students, it is also good programming. Further said that, if the student wants to be better at programming, it must be given the knowledge of mathematics to these students.

\section{Method}

This research was conducted at the Department of Informatics Management Undiksha, Singaraja Bali. The study was conducted during the first semester in the academic year 2018/2019, from September until December 2018. A quasi-experimental method and design of "treatment by the level of 2x2" were employed.

The target population in this study were all students of Informatic Management Faculty of Technology and Vocational Undiksha in the first semester in the academic year 2018/2019. In the first semester, there are two classes. They are A and B. Based on a review of existing documents about the data that the new students, both grade equivalent. It can be seen from the results of a significant $F$-test based on the analysis of variance of the entrance test scores through the SMBJM test in 2018.

In this study sampling, random sampling technique was used. In the first phase, the researchers chose both classes as samples of the research. Having obtained both classes in the sample, followed by randomly selecting one class as the experimental group and the other as the control group through the lottery technique. Members study sample were in each group are not all taken as the unit of analysis, but only taken groups of the upper and lower groups that meet criteria based on test results mathematical-logical intelligence. Based on the test results, the mathematical-logical intelligence massaged his score from higher to lower either the experimental group or the control group. The criteria of 33\% above and $33 \%$ below were used in the experimental group and the control group for the determination.

The data collected in this study were: 1) data result of learning computer programming obtained through multiple-choice test for cognitive and models of performance assessment for psychomotor, 2) data regarding the high and low intelligence mathematical-logical obtained through the provision of a questionnaire instrument mathematical-logic intelligence, and 3) the data obtained numerical talent by providing numerical aptitude test instruments to students. Giving a mathematical-logical intelligence instrument and numerical aptitude tests done before treatment is given. Third numerical data obtained by measuring the learning outcomes of learning through the score results of learning computer programming, mathematical-logical intelligence score, and numerical aptitude scores of students.

Instruments results in cognitive learning computer programming amounted to 60 grains, and psychomotor amounted to 6 grains. The validity of the content of these instruments was value by two experts. After assessed by two experts, then tested on 60 students. The trial results showed that there were 55 items with valid instrument reliability of 0.906 for cognitive 
and six items with reliabilities valid instrument of 0.853 . Instrument test results show mathematical-logical intelligence; there are 37 items valid statement of 40-point declaration tested. Calculating the coefficient of reliability of the instrument by using the Alpha Cronbach formula, obtained a value of 0.853 . The trial results demonstrated a numerical aptitude instrument, all valid items of 40 items tested. Calculating the coefficient of reliability of the instrument using the KR-20 formula, obtained a value of 0.856 .

Data analysis performed in this study, namely: 1) descriptive analysis, 2) analysis prerequisite test and 3) inferential analysis. The third analysis was conducted based on numerical aptitude scores, and scores of students who earned students' learning outcomes on computer programming after-treatment of the learning process are accompanied by portfolio assessment and project assessment.

\section{Result and Discussion}

Adolescence This study uses two levels of control factor by a factor (the covariate). A factor in this study is a factor in the type of assessment that consists of a portfolio assessment and project assessment. Factor $\mathrm{B}$ in this research is the mathematical-logical intelligence factors, which are divided into high mathematical-logical intelligence and low mathematicallogical intelligence. While the control factors (its covariate) is a numerical aptitude and $Y$ in this study is the result of learning computer programming. Full data presentation of the results of learning computer programming and numerical aptitude students who obtained from the research in each group are shown in Table 1.

Before data can be examined further, it is necessary to test the normality of the data, the data homogeneity, linearity test, and alignment of the regression line. Normality test is performed to determine whether the data from each of the groups come from populations with normal distribution or not. In this study, the test data normality was tested and analyzed with the assistance techniques Lilliefors test using Microsoft Excel 2007. Based on calculations Lilliefors normality test, it can be seen that all groups of the normal distribution of data, because all values obtained $L 0$ count smaller than the value $L t=0.05$ ). A table at a significance level of $5 \%$ (Thus, it can be concluded that all of the normal distribution of data distribution groups. For more details, normality test results for all groups of data can be viewed on a summary of the normality of the data in Table 2 below.

Table 1. Summary of Results Score Learning Computer Programming and Numerical Talent at All Research Group

\begin{tabular}{|c|c|c|c|c|c|c|c|}
\hline & \multirow{3}{*}{ B } & \multicolumn{4}{|c|}{ A } & \multirow{2}{*}{\multicolumn{2}{|c|}{$\Sigma$}} \\
\hline & & \multicolumn{2}{|c|}{ A1 } & \multicolumn{2}{|c|}{$\mathrm{A} 2$} & & \\
\hline & & $\mathbf{X}$ & $Y$ & $x$ & $Y$ & $\mathbf{x}$ & $\mathbf{Y}$ \\
\hline & $\mathbf{N}$ & 20 & 20 & 20 & 20 & 40 & 40 \\
\hline & $\bar{X} / \bar{Y}$ & 51.67 & 59.35 & 50.31 & 46.11 & 49.97 & 53.47 \\
\hline \multirow[t]{5}{*}{ B1 } & $\mathbf{S}$ & 10.47 & 3.78 & 10.64 & 4.83 & 10.56 & 7.33 \\
\hline & Min & 24.65 & 50.99 & 13.73 & 35.99 & 13.73 & 35.99 \\
\hline & Max & 62.86 & 67.31 & 62.86 & 55.74 & 62.86 & 67.31 \\
\hline & $\mathbf{N}$ & 20 & 20 & 20 & 20 & 40 & 40 \\
\hline & $\bar{X} / \bar{Y}$ & 48.26 & 46.95 & 49.76 & 47.60 & 50.03 & 46.53 \\
\hline \multirow[t]{3}{*}{ B2 } & $\mathbf{S}$ & 10.93 & 5.10 & 8.19 & 6.86 & 9.54 & 5.98 \\
\hline & Min & 32.84 & 37.40 & 35.57 & 34.82 & 32.84 & 34.82 \\
\hline & Max & 73.78 & 56.86 & 65.59 & 58.13 & 73.78 & 58.13 \\
\hline \multirow[t]{3}{*}{$\Sigma$} & $\mathbf{N}$ & 40 & 40 & 40 & 40 & 80 & 80 \\
\hline & $\bar{X} / \bar{Y}$ & 50.99 & 53.15 & 49.01 & 46.85 & 50.00 & 50.00 \\
\hline & $S$ & 10.59 & 7.69 & 9.40 & 5.90 & 10.00 & 7.51 \\
\hline
\end{tabular}




\begin{tabular}{|c|c|c|c|c|c|c|}
\hline \multirow{3}{*}{ B } & \multicolumn{4}{|c|}{ A } & \multirow{2}{*}{\multicolumn{2}{|c|}{$\Sigma$}} \\
\hline & \multicolumn{2}{|c|}{ A1 } & \multicolumn{2}{|c|}{$\mathrm{A} 2$} & & \\
\hline & $\mathbf{X}$ & $\mathbf{Y}$ & $\mathbf{X}$ & $\mathbf{Y}$ & $\mathbf{X}$ & $\mathbf{Y}$ \\
\hline Min & 24.65 & 37.40 & 13.73 & 34.82 & 13.73 & 34.82 \\
\hline Max & 73.78 & 67.31 & 65.59 & 58.13 & 73.78 & 67.31 \\
\hline
\end{tabular}

Table 2. Summary of Results Calculations Learning Outcomes Data Normality Test Computer Programming

\begin{tabular}{ccccl}
\hline Group & $\mathbf{N}$ & $\mathbf{L}_{\mathbf{0}}$ & $\mathbf{L}_{\mathbf{t}}$ & Conclusion \\
\hline $\mathrm{A}_{1}$ & 40 & 0.0844 & 1.40 & Normal distribution \\
$\mathrm{A}_{2}$ & 40 & 0.0936 & 1.40 & Normal distribution \\
$\mathrm{B}_{1}$ & 40 & 0.0824 & 1.40 & Normal distribution \\
$\mathrm{B}_{2}$ & 40 & 0.0772 & 1.40 & Normal distribution \\
$\mathrm{A}_{1} \mathrm{~B}_{1}$ & 20 & 0.1264 & 1.90 & Normal distribution \\
$\mathrm{A}_{1} \mathrm{~B}_{2}$ & 20 & 0.0764 & 1.90 & Normal distribution \\
$\mathrm{A}_{2} \mathrm{~B}_{1}$ & 20 & 0.0936 & 1.90 & \\
$\mathrm{~A}_{2} \mathrm{~B}_{2}$ & 20 & 0.1099 & 1.90 & \\
\hline
\end{tabular}

After normality test data, then the next step is to test the homogeneity of the data. Testing homogeneity of variance in this study done to test the homogeneity of variance for two groups of data, i.e., between groups $A$ and $B$ between groups, as well as the homogeneity of variance test for each group, namely (A1B1, A1B2, A2B1, A2B2). Testing for inter-group variance between groups $A$ and $B$, using the $F$-test, while testing for variants of each group formed by the factors A and B, using Bartlett test. Group data to be tested, it must meet the assumptions that have the same variance (homogeneous).

F-test was used to test the homogeneity of the data that comprises two groups of data. The homogeneity test was done between data groups $A 1$ and $A 2$ groups, as well as test the homogeneity between groups B1 and B2. The formula used to test the homogeneity between the two data sets is as follows.

$$
F=\frac{\text { Varians } 1}{\text { Varians } 2} \text { (Bruning, 1977:109) }
$$

Where variants 1 is the largest variance, and variant 2 is the smallest variance.

The formula is based on the hypothesis that will be tested are:

$\mathrm{H}_{0}: \sigma_{1}^{2}=\sigma_{2}^{2}$ (variance two groups of equal or homogeneous)

$\mathrm{H}_{1}: \sigma_{1}^{2} \neq \sigma_{2}^{2}$ (variance of the two groups different or not homogeneous)

Tests conducted at a significance level $\alpha=0.05$ by comparing the value of $F_{\text {counting }}$ and

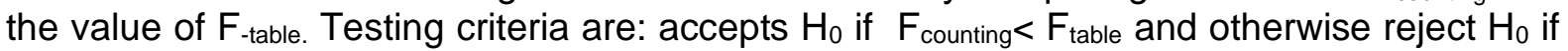
$F_{\text {counting }}>F_{\text {-table. }}$. By using Microsoft Excel 2007 program obtained the following results.

First, test the homogeneity of data between groups $A_{1}$ dan $A_{2}$. Based on calculations, the value of $F_{\text {counting }}=1,69$ with the value of $F_{\text {-table } 0,975 \text { dan } 0,025}=(0,546 ; 1,832)$ at significance level $\alpha=0,05$ and $\mathrm{dk}_{1}=(40 ; 39)$ it means $\mathrm{F}_{\text {tabel0,975(40;39) }}=0,546<\mathrm{F}_{\text {counting }}=1,69<\mathrm{F}_{\text {table } 0,025(40 ; 39)}=1,832$, so $\mathrm{H}_{0}$ is therefore concluded that the groups $A_{1}$ and $A_{2}$ have variances were homogeneous.

Second, testing the homogeneity of data between the $B_{1}$ and $B_{2}$. Based on calculations, the value of $F_{\text {counting }}=1,50$ with the value of $F_{\text {table } 0,975}$ and $0,025=(0,546 ; 1,832)$ at significance level $\alpha=0,05$ and $\mathrm{dk}_{1}=(40 ; 39)$ it means $F_{\text {table } 0,975(40 ; 39)}=0,546<F_{\text {counting }}=1,50<F_{\text {table } 0,025(40 ; 39)}=1,832$, so $\mathrm{H}_{0}$ is therefore concluded that the group $\mathrm{B}_{1}$ and $\mathrm{B}_{2}$ have variances were homogeneous. 
Furthermore, the Bartlett test used to test the homogeneity of variance in all four groups of data formed by a factor $A$ and factor $B$, namely $\left(A_{1} B_{1}, A_{1} B_{2}, A_{2} B_{1}, A_{2} B_{2}\right)$. To be able to test Bartlett, it is necessary to work the tables, as shown in Table 3. Based on the worktable can be calculated magnitude of the combined variance, log variance, the value of $B$, and the price $\chi^{2}$ Bartlett or $\chi^{2}$ hitung.

Table 3. Table Work for Calculating Homogeneity

\begin{tabular}{|c|c|c|c|c|c|}
\hline Group & $\mathrm{Db}$ & $1 / \mathrm{db}$ & $\mathrm{S}_{\mathrm{i}}{ }^{2}$ & $\log S_{i}^{2}$ & db. $\log S_{i}^{2}$ \\
\hline 1 & 19 & 0.0526 & 14.2792 & 1.1547 & 21.9394 \\
\hline 2 & 19 & 0.0526 & 26.0310 & 1.4155 & 26.8943 \\
\hline 3 & 19 & 0.0526 & 23.2776 & 1.3669 & 25.9718 \\
\hline 4 & 19 & 0.0526 & 47.0497 & 1.6726 & 31.7786 \\
\hline Total & 76 & - & - & - & 106.5841 \\
\hline
\end{tabular}

By using the Bartlett test, obtained, $\chi^{2}$ counting is equal to 6,89 , while the value of $\chi^{2}$ in the table to the significance level $\alpha=0,05$; $d k=3$ is equal to 7,81 . It indicates that the value of $\chi^{2}$ counting $=6,89$ is smallest than the value of $\chi^{2}$ in the table to the significance level $\alpha=0,05$; $\mathrm{dk}=3$, namely 7,81 . Thus the variance of scores of each group of data is homogeneous. In other words, the four groups of data derived from a homogeneous population. The next step is to test the linearity to determine whether the regression model covariates $X$ on the dependent variable $Y$ be linear or not. Based on the test results with the help of the SPSS application program, obtained the results, as shown in Table 4.

Table 4. Linearity Test Results Using SPSS

\begin{tabular}{|c|c|c|c|c|c|c|c|}
\hline & & & $\begin{array}{l}\text { Sum of } \\
\text { Squares }\end{array}$ & df & $\begin{array}{l}\text { Mean } \\
\text { Square }\end{array}$ & $\mathbf{F}$ & Sig. \\
\hline \multirow{5}{*}{$\begin{array}{l}\text { Learning } \\
\text { Outcomes } \\
\text { Programming * } \\
\text { Numerical Talent }\end{array}$} & \multirow{3}{*}{$\begin{array}{l}\text { Between } \\
\text { Groups }\end{array}$} & (Combined) & 1225.712 & 16 & 76.607 & 1.494 & .130 \\
\hline & & Linearity & 110.053 & 1 & 110.053 & 2.147 & .148 \\
\hline & & $\begin{array}{l}\text { Deviation from } \\
\text { Linearity }\end{array}$ & 1115.659 & 15 & 74.377 & 1.451 & .152 \\
\hline & \multicolumn{2}{|c|}{ Within Groups } & 3229.962 & 63 & 51.269 & & \\
\hline & \multicolumn{2}{|l|}{ Total } & 4455.675 & 79 & & & \\
\hline
\end{tabular}

Table 4 shows that, Fhit value in Deviation from Linearity of 1.451 with a significance value (sig.) of 0.152 . If the specified level of significance $\alpha=0,05$, so the value of sig. is higher than $\alpha$, and the value of $F_{\text {hit }}$ is smaller than $F_{\text {tabel }(\alpha=0,05)}=3,98$. Thus, the null hypothesis is accepted, and the alternative hypothesis is rejected. The conclusion is a model of the linear regression of all cells at the significance level $\alpha=0.05$.

Next is testing the alignment of the regression line. Test alignment regression line was conducted in order to determine whether the coefficient of direction or the inclination or slope of the regression line effect of covariates that talent numeric $(X)$ on the dependent variable is the result of learning computer programming $(Y)$. From each sample group formed by factors of assessment types (A) and logical-mathematical intelligence factor (B) is parallel (homogeneous) or not. The forms of statistical hypothesis can be stated as follows.

The forms of statistical hypothesis can be stated as follows.

$$
\begin{array}{ll}
\mathrm{H}_{0}:\left[F S^{*} X\right]_{s}=0 \text { for all s } & \text { (regression of all the cells in parallel). } \\
\mathrm{H}_{1}: \text { does not } \mathrm{H}_{0} & \text { (these regressions are not parallel). }
\end{array}
$$

Testing this hypothesis, using SPSS with the procedure GLM (general linear model) univariate design: FS FS $X{ }^{*} X$. The testing process is done with the above hypothesis test for 
sources of variance $F S F^{*} X$ using $\alpha=0,05$ with the testing criteria is $\mathrm{H}_{0}$ accepted when $\mathrm{F}_{\text {counting }}$ $<\mathrm{F}_{\text {-table. }}$ Based on the analysis using SPSS, obtained prices, as shown in Table 5 below.

Table 5. Regression Line Alignment Test Results

\begin{tabular}{lrrrrrr}
\hline \multicolumn{1}{c}{$\begin{array}{l}\text { Variants } \\
\text { Resource }\end{array}$} & \multicolumn{1}{c}{ JK res } & \multicolumn{1}{c}{ db } & \multicolumn{1}{c}{ RJK } & F $_{\text {counting }}$ & Sig. & F $_{\text {-table }}$ \\
\hline Corrected Model & $905.537^{\mathrm{a}}$ & 3 & 301.846 & 6.462 & .001 & \\
Intercept & 6319.930 & 1 & 6319.930 & 135.295 & .000 & \\
$\mathrm{X}$ & 46.342 & 1 & 46.342 & .992 & .322 & \\
$\mathrm{FS}$ & 3.520 & 1 & 3.520 & .075 & .784 & \\
FS ${ }^{*} \mathrm{X}$ & 53.296 & 1 & 53.296 & 1.141 & .289 & 3.96 \\
Error & 3550.138 & 76 & 46.712 & & & \\
\hline Total & $\mathbf{2 0 4 4 5 5 . 6 7 5}$ & $\mathbf{8 0}$ & & & & \\
\hline Corrected Total & $\mathbf{4 4 5 5 . 6 7 5}$ & $\mathbf{7 9}$ & & & &
\end{tabular}

Based on Table 5 above, it appears that $F_{\text {counting }}=\mathbf{1 , 1 4 1}$ dan $F_{\text {table }}=\mathbf{3 , 9 6}$ at significance level $\alpha=0,05$. It is why $F_{\text {counting }}=1,141<F_{\text {table }}=3,96$. It means $H_{0}$ is accepted, so it can be concluded that there is no difference in the slope of the regression line (slopes) of all cells that form factor by factor assessment types $(A)$ by a factor of logical-mathematical intelligence ( $B)$, in other words, that the regression of the four cells in parallel.

After all of the terms associated with the statistical parametric analysis of covariance (ANCOVA) as above have been fulfilled, then for further inferential analysis in order to test the research hypothesis by using statistical techniques of analysis of covariance (ANCOVA).

A. Results of learning computer programming students who attend the learning process with portfolio assessment are higher than the students who attend the learning process with the assessment project, after controlling numerical aptitude.

The statistical hypothesis can be written:

$\mathrm{H}_{0}: \mu \mathrm{A}_{1} \leq \mu \mathrm{A}_{2}$

$\mathrm{H}_{1}: \mu \mathrm{A}_{1}>\mu \mathrm{A}_{2}$

Where the symbol $\mu A_{i}$, stating the average corrected $Y$, assuming a linear effect of $X$ on $Y$ the same in both groups $A_{1}$ and $A_{2}$. By using SPSS, with the GLM Univariate procedure, the result, as shown in Table 6.

Based on the analysis, as shown in Table 6, shows that the statistical value of Test-F above the line $A$ obtained value $F_{\text {counting }}=35,118$ is bigger than $F_{\text {table(1;75) }}=3,96$ at significance level $\alpha=0,05$. It means that $H_{0}$ is rejected. Thus, it can be concluded that the results of learning computer programming on a group of students who follow the learning process with portfolio assessment are higher than the group of students who follow the learning process with the assessment project after controlling the numerical aptitude of students. 
Table 6. The test statistic-F on $A, A^{*} B$ toward learning outcomes Computer Programming with Numerical Control Talents

\begin{tabular}{|c|c|c|c|c|c|c|}
\hline \multirow{2}{*}{ Variants Resource } & \multirow{2}{*}{ JK res } & \multirow{2}{*}{$\mathbf{d b}$} & \multirow{2}{*}{ RJK } & \multirow[t]{2}{*}{$\mathbf{F}$} & \multicolumn{2}{|c|}{$\begin{array}{c}\text { Counting } \\
\text { F-table }\end{array}$} \\
\hline & & & & & $\alpha=0,05$ & $\alpha=0,01$ \\
\hline Corrected Model & $2390.638^{a}$ & 4 & 597.660 & 21.706 & & \\
\hline Intercept & 6489.169 & 1 & 6489.169 & 235.680 & & \\
\hline x & 36.997 & 1 & 36.997 & 1.344 & & \\
\hline$A$ & 966.944 & 1 & 966.944 & 35.118 & 3.96 & 6.96 \\
\hline B & 751.005 & 1 & 751.005 & 27.276 & & \\
\hline$A * B$ & 571.076 & 1 & 571.076 & 20.741 & & \\
\hline Error & 2065.036 & 75 & 27.534 & & & \\
\hline Total & 204455.675 & 80 & & & & \\
\hline Corrected Total & 4455.675 & 79 & & & & \\
\hline
\end{tabular}

$B$. In the group of students who have high logical-mathematical intelligence $\left(B_{1}\right)$, the result of learning computer programming $(Y)$ students who attend the learning process with portfolio assessment $\left(A_{1}\right)$, higher than the group of students who attend the learning process with the assessment project $\left(A_{2}\right)$, after controlling numerical aptitude $(X)$

The statistical hypothesis to be tested are as follows:

$H_{0}: \mu A_{1} B_{1} \leq \mu A_{2} B_{1}$

$H_{1}: \mu A_{1} B_{1}>\mu A_{2} B_{1}$

Testing the hypothesis above using SPSS with the procedure GLM Univariate with (design: $X B A^{*} B$ ). The test results with the SPSS program are presented in Table 7 below.

Table 7. Statistics t-test on Parameter Mean $Y$ between All Levels A Factor for Each Level Control Factor $B$ with $\mathrm{X}$

\begin{tabular}{|c|c|c|c|c|c|c|}
\hline \multirow{2}{*}{ Parameter } & \multirow{2}{*}{$\begin{array}{c}\text { Symbol } \\
\text { Parameter }\end{array}$} & \multirow{2}{*}{ B } & \multirow{2}{*}{ Std. Error } & \multirow{2}{*}{$\mathbf{t}$} & \multicolumn{2}{|c|}{$\begin{array}{c}\text { Counting } \\
\text { t-table }\end{array}$} \\
\hline & & & & & $\alpha=0,05$ & $\alpha=0,01$ \\
\hline Intercept & $\beta_{0}$ & 42.674 & 3.185 & 13.399 & & \\
\hline$X$ & $\delta_{0}$ & .069 & .060 & 1.159 & & \\
\hline$[\mathrm{B}=1]$ & $\beta_{1}$ & .801 & 1.660 & .483 & & \\
\hline$[\mathrm{B}=2]$ & - & $0^{\mathrm{a}}$ & & . & 1,68 & 2,39 \\
\hline$[A=1]^{*}[B=1]$ & $\beta_{2}$ & 12.311 & 1.661 & 7.410 & & \\
\hline$[A=1]^{*}[B=2]$ & $\beta_{3}$ & 1.596 & 1.662 & .960 & & \\
\hline$[A=2]^{*}[B=1]$ & & $0^{a}$ & & & & \\
\hline$[\mathrm{A}=2]^{*}[\mathrm{~B}=2]$ & & $0^{a}$ & & & & \\
\hline
\end{tabular}

Based on the analysis of hypothesis testing using SPSS through the procedure GLM Univariate, as shown in Table 7 above, shows that the value of statistical t-test line $\left[(A=1)^{*}(B=1)\right]$ obtained values $t_{\text {-count }}$ ing $=7,410$ is more significant than $t$-table(40) $=1,684$ at significance level $\alpha=0,05$, so $\mathrm{H}_{0}$ is rejected. Thus, it can be concluded that a particular group of students who have high logical-mathematical intelligence, computer programming learning outcomes in the group of students who attend the learning process with portfolio assessment is higher than the group of students who attend the learning process with the assessment project, after controlling numerical aptitude. 
$C$. In the group of students who have a low logical-mathematical intelligence $\left(B_{2}\right)$, the result of learning computer programming $(Y)$ students who attend the learning process with the assessment project $\left(A_{2}\right)$, is higher than the students who attend the learning process with portfolio assessment $\left(A_{1}\right)$, after controlling numerical aptitude $(X)$

The statistical hypothesis tested were as follows:

$$
\begin{aligned}
& \mathrm{H}_{0}: \mu \mathrm{A}_{1} \mathrm{~B}_{2} \geq \mu \mathrm{A}_{2} \mathrm{~B}_{2} \\
& \mathrm{H}_{1}: \mu \mathrm{A}_{1} \mathrm{~B}_{2}<\mu \mathrm{A}_{2} \mathrm{~B}_{2}
\end{aligned}
$$

Based on the analysis, as shown in Table 7 above, it can be seen that the statistical value of the t-test online $\left[(A=1)^{*}(B=2)\right]$ obtained values $t$-counting $=0,960$ is smaller than $t_{\text {-table }}=$ 1,684 at significance level $\alpha=0,05$, so $\mathrm{H}_{0}$ is rejected. Thus, it can be concluded that a special group of students who have low logical-mathematical intelligence, computer programming learning outcomes between groups of students who attend the learning process with the assessment project is higher than the group of students who attend the learning process with portfolio assessment, after controlling numerical aptitude.

\section{Conclusion}

Results of learning computer programming for groups of students who attend the learning process with portfolio assessment is higher than the group of students who attend the learning process with the assessment project, after controlling for student numerical aptitude. There is an interaction effect between the type of assessment and mathematicallogical intelligence to computer programming learning outcomes, after controlling for student numerical aptitude. In the group of students who have high mathematical-logical intelligence, learning outcomes computer programming student groups follow the learning process with portfolio assessment is higher than the group of students who attend the learning process with the assessment project after controlling numerical aptitude of students. In the group of students who have low mathematical-logical intelligence, learning outcomes computer programming student groups follow the learning process with the assessment project is higher than the group of students who attend the learning process with portfolio assessment, after controlling for student numerical aptitude. Research suggests using the type of portfolio assessment in the learning process in order to improve student results.

\section{References}

Bruning, James L. 1977. Computational Handbook of Statistics. United State of America: Scott, Foresman and Company.

Budiningsih, C. Asri. 2012. Belajar \& Pembelajaran. Jakarta: Rineka Cipta.

Doran, Rodney, Fred Chan, dan Pinchas Tamir. 1998. Science Educator's Guide To Assessment. Virginia: National Science Teachers Association.

Gardner, Howard. 2003. Multiple Intelligences (Terjemahan oleh Alexander Sindoro). Batam: Interaksara.

Johnson, David W., dan Roger T. Johnson. 2002. Meaningful Assessment A Manageable and Cooperative Process. Boston: A Pearson Education Company.

Koyan, I Wayan. 2011. Asesmen Dalam Pendidikan. Singaraja: Undiksha Press.

Mahardika, I Made Sriundy. 2010. Pengantar Evaluasi Pengajaran. Surabaya: Unesa University Press.

Mandiartha, I Wayan. 2011. "Menyusun Tes Prestasi Belajar Biologi Berbasiskan Standar Kompetensi". Makalah Seminar IImiah Penyusunan Tes Prestasi Belajar Berbasiskan Pola KTSP. Gerokgak.

Marhaeni, A.A.I.N. 2004. "Portofolio Sebagai Pendekatan Asesmen dalam Pembelajaran." Jurnal Pendidikan dan Pengajaran.

Martin, V. Maria Antoniate, dan T. Lucia Agnes Beena. 2012. "Prediction of Association among Numerical Aptitude, Programming Skills, Trait Emotional Intelligence on Students Performance." International Journal on Computer Science and Engineering (IJCSE). 
Munandar, Utami. 1992. Pengembangan Bakat dan Kreativitas Anak Sekolah. Jakarta: Grasindo.

Nurkancana, Wayan. 1993. Pemahaman Individu. Surabaya: Usaha Nasional.

Plimmer, Beryl. 2000. "A Case Study of Portfolio Assessment in a Computer Programming Course." Proceedings of the NACCQ 2000. Wellington New Zealand: NACCQ.

Radili, Leny. 2009. lenyradili89.blogspot.com. http://lenyradili89.blogspot.com/ 2009/12/bakat-khusus.html (diakses 15 Mei, 2013).

Sanjaya, H. Wina. 2010. Kurikulum dan Pembelajaran. Jakarta: Kencana Prenada Media Group.

Sudjana, Nana. 2002. Penilaian Hasil Proses Belajar Mengajar. Bandung: Remaja Rosdakarya Offset.

Uno, Hamzah B., dan Satria Koni. 2012. Assessment Pembelajaran. Jakarta: Bumi Aksara.

Wortham, Sue C. 2008. Assessment in Early Childhood Education. New Jersey: Pearson Education, Inc. 